\title{
The effect of tubeimoside-I on the proliferation, metastasis and apoptosis of oral squamous cell carcinoma in vitro
}

This article was published in the following Dove Press journal:

OncoTargets and Therapy

\author{
Tingting $\mathrm{Wu}^{1-4}$ \\ Hongjuan $\mathrm{Cui}^{5}$ \\ Yamei $X u^{1-4}$ \\ Quangao $\mathrm{Du}^{1-4}$ \\ Erhu Zhao ${ }^{5}$ \\ Jiangjun $\mathrm{CaO}^{5}$ \\ Ling $\mathrm{Nie}^{1-4}$ \\ Gang Fu ${ }^{1-4}$ \\ Aishu Ren ${ }^{1-3,6}$ \\ 'College of Stomatology, Chongqing \\ Medical University, Chongqing, \\ People's Republic of China; \\ ${ }^{2}$ Chongqing Key Laboratory of Oral \\ Diseases and Biomedical Sciences, \\ Stomatological Hospital of Chongqing \\ Medical University, Chongqing, \\ People's Republic of China; \\ ${ }^{3}$ Chongqing Municipal Key Laboratory \\ of Oral Biomedical Engineering of \\ Higher Education, Stomatological \\ Hospital of Chongqing Medical \\ University, Chongqing, People's \\ Republic of China; ${ }^{4}$ Department of \\ Oral Implantology, Stomatological \\ Hospital of Chongqing Medical \\ University, Chongqing, People's \\ Republic of China; ${ }^{5}$ State Key \\ Laboratory of Silkworm Genome \\ Biology, Southwest University, \\ Chongqing, People's Republic of \\ China; 'Department of Orthodontics, \\ Stomatological Hospital of Chongqing \\ Medical University, Chongqing, \\ People's Republic of China
}

Correspondence: Aishu Ren

Department of Orthodontics, Stomatological Hospital of Chongqing

Medical University, \# 426, North

Songshi Road, Chongqing 40II47,

People's Republic of China

Tel +862389031056

Email rasras@।63.com
Background: Tubeimoside-1 (TBMS1), a triterpenoid saponin extracted from traditional Chinese medicine tubeimoside, exerts a cytotoxic effect on several human cancer cell lines. However, no study has focused on whether TBMS1 works on oral squamous cell carcinoma (OSCC).

Materials and methods: We treated OSCC cells with TBMS1 to detect the effect and relevant molecular basis of TBMS1 for the first time. We chose two oral cancer cell lines, CAL27 and SCC15, for this study. First, the 3-(4,5-dimethylthiazol-2-yl)-2,5-diphenylte-trazolium bromide assay and cell proliferation $5^{\prime}$-bromo- $2^{\prime}$-deoxyuridine assay were carried out to detect cell growth. Second, colony formation assay was performed to assess clonogenesis capacity. Next apoptosis was analyzed by flow cytometry. Subsequently, wound healing and transwell assays were applied to explore cell migration. Finally, Western blot was further performed to examine corresponding proteins' expression change.

Results: Our data showed that TBMS1 significantly suppressed proliferation of OSCC cells in a dose- and time-dependent manner and it inhibited migration of OSCC cells as well. After treatment with TBMS1, OSCC cells underwent cell apoptosis. Furthermore, Western blot demonstrated that TBMS1 downregulated apoptosis-associated proteins such as PARP, p-ERK1/2, Bcl-2, caspase-3, caspase- 7 and caspase- 8 and upregulated cleaved PARP, cleaved caspase-3 and cleaved caspase-9. It could also reduce expression of c-Myc and MMP-7. Meanwhile, TBMS1 did not change the total ERK1/2 expression.

Conclusion: These results revealed that TBMS1 might be a potential chemotherapeutic drug for the management of OSCC.

Keywords: tubeimoside-1, chemotherapeutic drug, oral squamous cell carcinoma, OSCC, apoptosis, underlying mechanism

\section{Introduction}

Oral cancer is one of the most common malignant tumor types, which ranks sixth among the cancers occurring worldwide, with $90 \%$ of oral cancer being classified as oral squamous cell carcinoma (OSCC). ${ }^{1}$ It is also one of the main causes of cancer-related death. When detected in advanced stage, OSCC with the highest incidence among the oral cancers may be incurable and has low 5-year survival rate. Surgery, radiotherapy and chemotherapy are the main therapeutic methods of OSCC at present. Although considerable improvements have been achieved in diagnostic and treatment strategies in recent years, the 5-year survival rate of OSCC patients, especially in the advanced stage, is still low, which mainly is due to poor therapeutic response, recurrence and metastasis. So, currently, there is no ideal treatment method and medicine for oral cancer. It is very urgent to seek a more effective anti-cancer drug to conquer OSCC and improve prognosis. 
"Tu-Bei-Mu," namely a medical plant Bolbostemma paniculatum (Maxim) Franquet (Cucurbitaceae), has been widely used for many years in Chinese folk medicine. Its stem block is applied to treat numerous diseases such as breast carcinoma and cyclomastopathy. ${ }^{2}$ Tubeimoside-1 (TBMS1), one of the main active ingredients of "Tu-Bei-Mu", was first isolated in the early 1980 s and since then many scholars have begun to study its chemical structure (Figure 1A) and biological activities. Previous studies indicate that it has the following biological actions including anti-inflammatory,
A

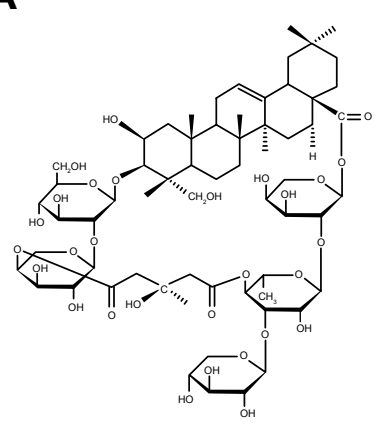

C
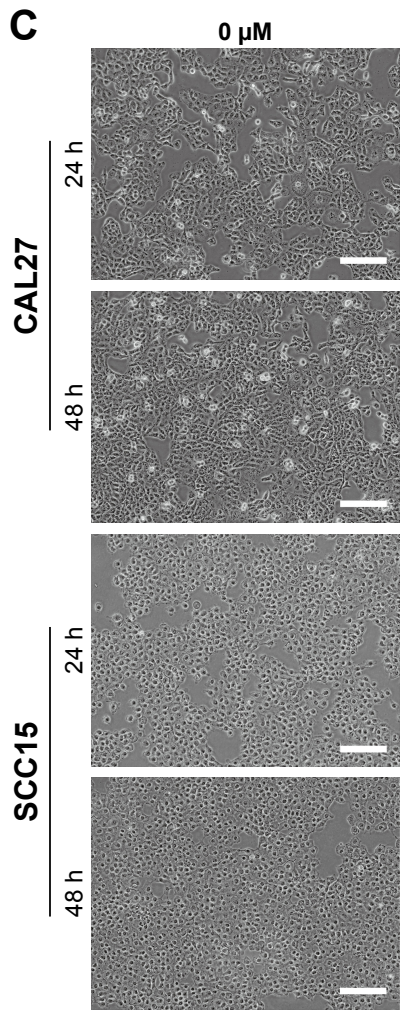

D

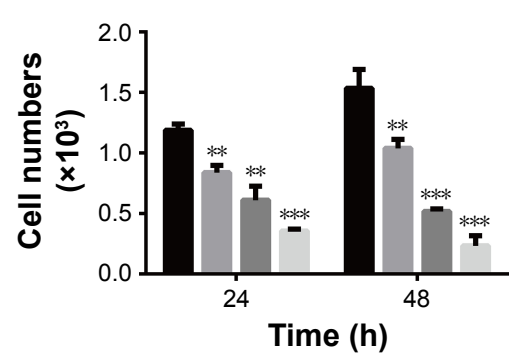

CAL27

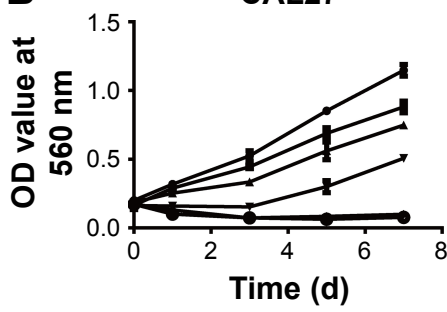

$\rightarrow 0 \mu \mathrm{M} \rightarrow 2.5 \mu \mathrm{M} \neq 5 \mu \mathrm{M} \rightarrow 10 \mu \mathrm{M} \leftarrow 15 \mu \mathrm{M} \leftarrow 20 \mu \mathrm{M}$
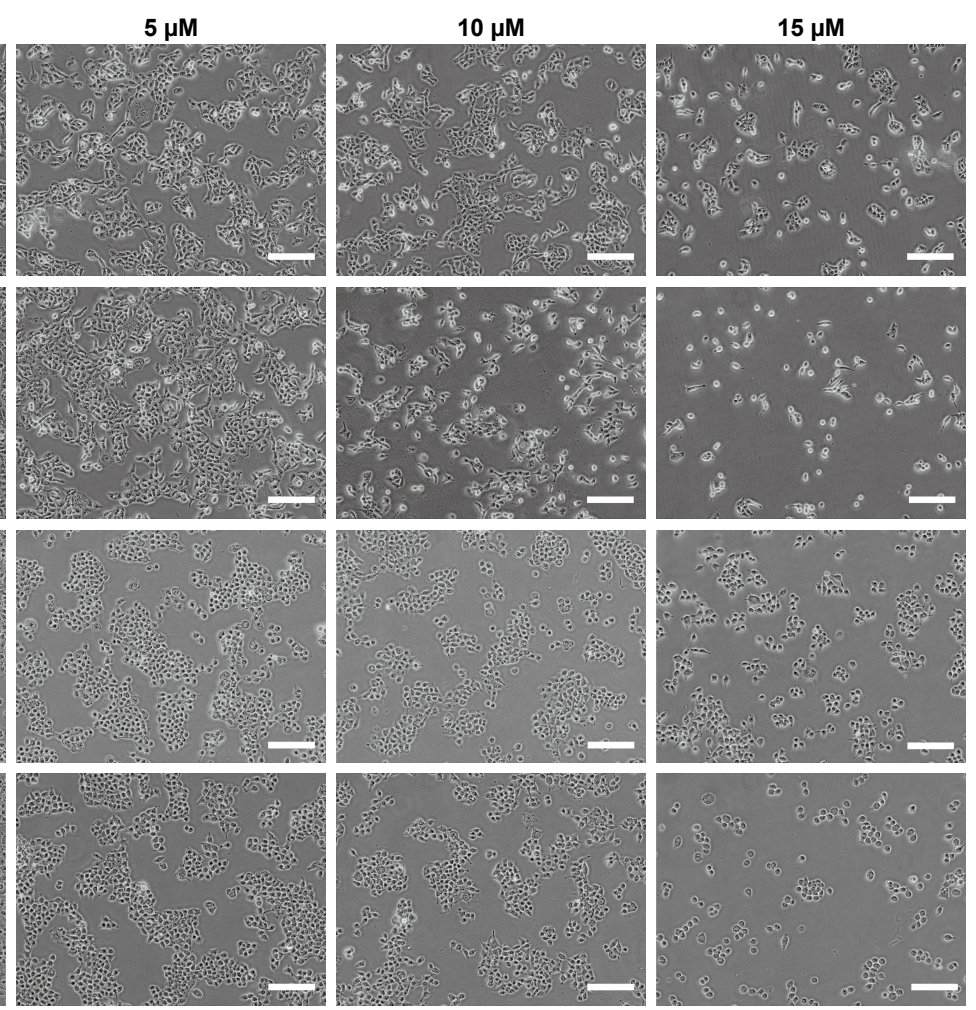

$\operatorname{scc} 15$

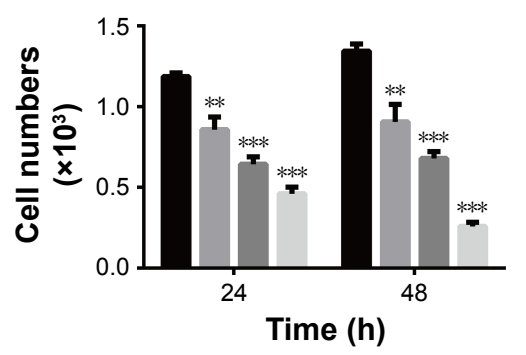

$0 \mu \mathrm{M} \square 5 \mu \mathrm{M} \square 10 \mu \mathrm{M} \square 15 \mu \mathrm{M}$ 


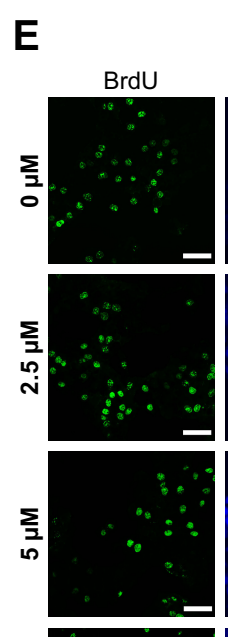

CAL27
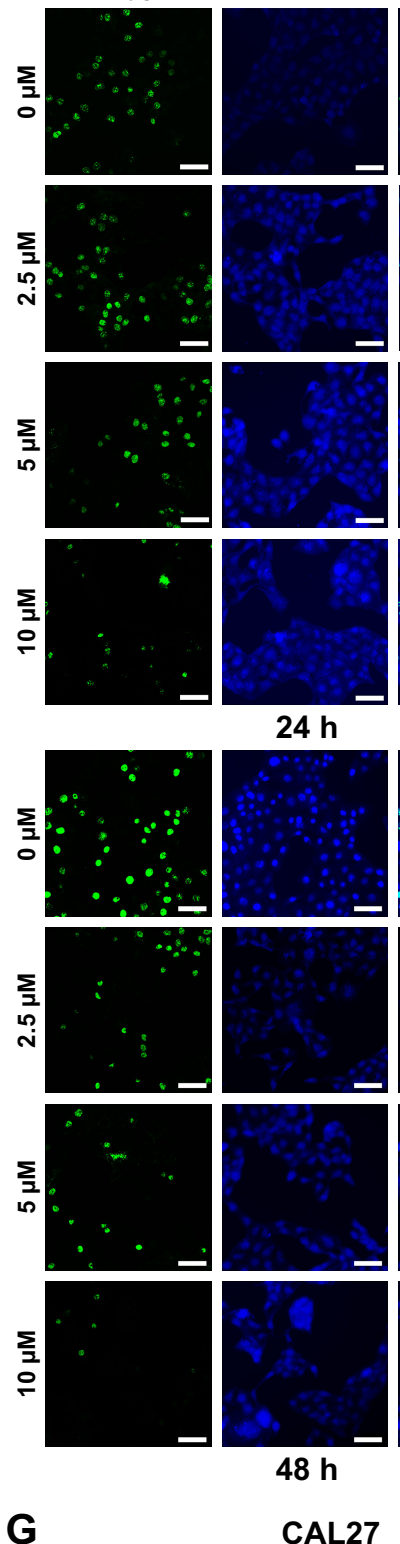

G

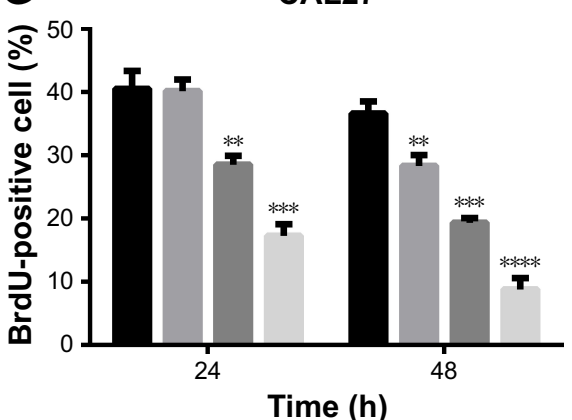

DAPI

$24 \mathrm{~h}$

$48 \mathrm{~h}$

$\mathbf{F}$

Merge
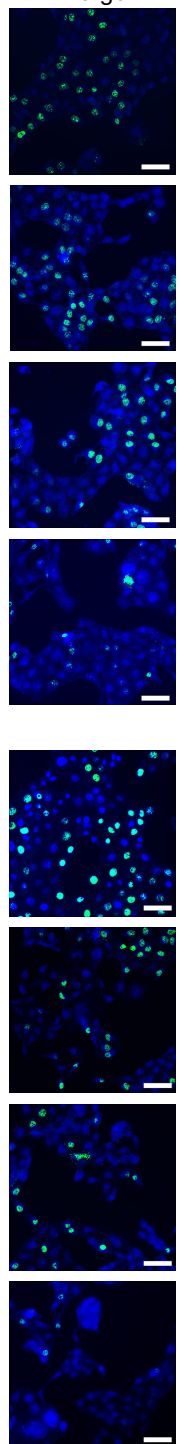

CAL27

Time (h)

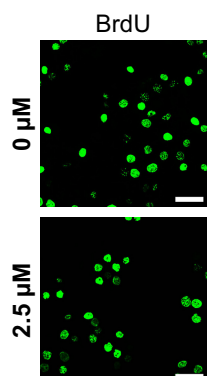

SCC15
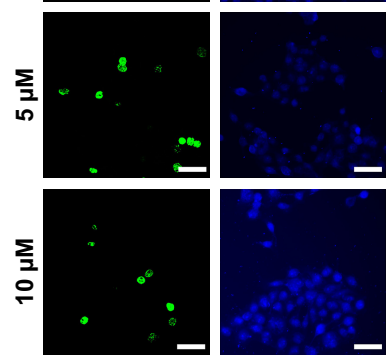

$24 \mathrm{~h}$
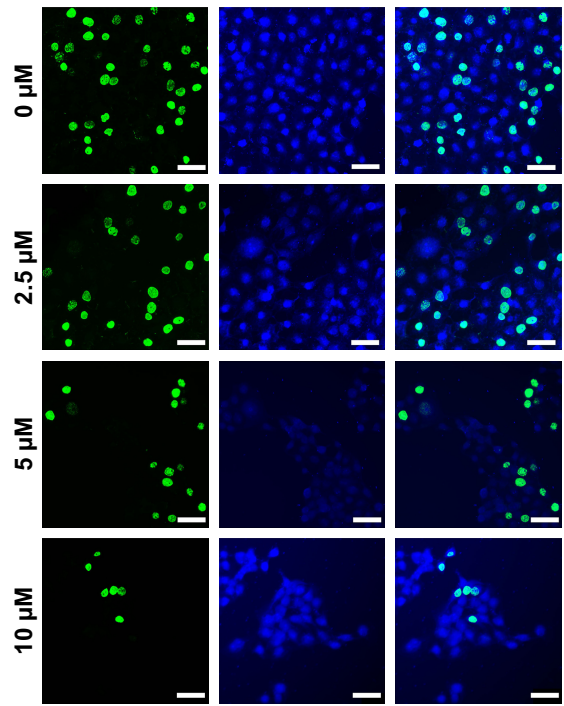

$48 \mathrm{~h}$

$\operatorname{scc} 15$

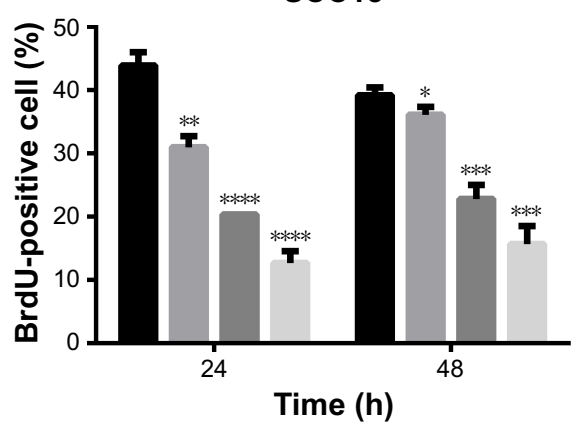

$\square \mu \mathrm{M}-2.5 \mu \mathrm{M} \square 5 \mu \mathrm{M} \square 10 \mu \mathrm{M}$

Figure I TBMSI induced proliferation inhibition and morphological change in OSCC cells.

Notes: (A) Chemical structure of TBMSI. (B) Cell viability was explored by MTT assay at 0, I, 3, 5 and 7 days. (C and D) Cell numbers were counted, and cell morphological change was observed after cells being treated with TBMSI for 24 and $48 \mathrm{~h}$. Scale bar $100 \mu \mathrm{m}$. (E and F) After cells being treated with TBMSI for 24 and $48 \mathrm{~h}$, images of BrdUpositive cells were captured. Scale bar $50 \mu \mathrm{m}$. (G) The percentages of BrdU-positive cells were calculated and statistically analyzed. All data were presented as mean \pm SD. $* P<0.05$, $* * P<0.01$, *** $P<0.001$, ****P $<0.0001$ compared with the control group $(0 \mu \mathrm{M})$.

Abbreviations: $\mu \mathrm{M}, \mu \mathrm{mol} / \mathrm{L}$; d, days; h, hours; TBMSI, tubeimoside-I; OSCC, oral squamous cell carcinoma; MTT, 3-(4,5-dimethylthiazol-2-yl)-2,5-diphenylte-trazolium bromide; BrdU, 5-bromo-2-deoxyuridine; DAPI, 4',6-diamidino-2-phenylindole. 
anti-tumor and immunosuppressive effects. Among them, the anti-tumor effect has sparked wide attention and currently a growing body of studies focusing on its anti-tumor effect have been conducted in vivo or vitro. It showed that TBMS1 could induce cell cycle arrest and apoptosis in HeLa cells. ${ }^{3,4}$ TBMS1-treated lung cancer cells underwent cell apoptosis through activating the MAPK-JNK signaling pathway, upregulating $\mathrm{Bax}$ to $\mathrm{Bcl}-2$ ratio and downregulating COX-2 expression. ${ }^{5,6}$ However, the role that TBMS1 plays in OSCC cells and the underlying mechanism are ill-defined. Hence, in the study, we explored the effect and the correlative molecular mechanisms of TBMS1 in OSCC cells.

\section{Materials and methods}

\section{Reagents}

TBMS1, bought from National Institute for the control of Pharmaceutical and Biological Products (Beijing, China) with purity $>98 \%$ by high-performance liquid chromatography (HPLC), was dissolved in DMSO to get a stock solution of $20 \mathrm{mmol} / \mathrm{L}$ and stored at $-20^{\circ} \mathrm{C}$. The stock solution was subsequently diluted to the desired concentration by a $1: 1$ mixture of DMEM/F12 medium when used (concentration of DMSO < $1 \%$ ). Dulbecco's Modified Eagle's Medium (DMEM), Ham's nutrient mixture F12, fetal bovine serum (FBS), paraformaldehyde and agarose were obtained from Thermo Fisher Scientific (Waltham, MA, USA). Propidium iodide (PI) was bought from BD Biosciences (San Jose, CA, USA). Phosphatase inhibitor, the 3-(4,5dimethylthiazol-2-yl)-2,5-diphenyltetrazolium bromide (MTT), 5'-bromo-2'-deoxyuridine (BrdU), 4',6-diamidino2-phen-ylindole (DAPI) and polyvinylidene difluoride (PVDF) membrane were purchased from EMD Millipore (Billerica, MA, USA). Mouse monoclonal anti-c-Myc and anti-GAPDH were obtained from Abcam (Cambridge, UK). Rabbit monoclonal anti-PARP, anti-cleaved PARP (c-PARP), anti-caspase-3, anti-caspase-7, anti-caspase-8, anti-cleaved caspase-3 (c-caspase-3), anti-cleaved caspase- 9 (c-caspase-9), anti-Bcl-2, anti-ERK1/2, anti-p-ERK1/2 and anti-MMP-7 were purchased from Cell Signaling Technology (Danvers, MA, USA). All antibodies were diluted according to the manufacturer's instructions.

\section{Cell lines and cell culture}

OSCC cell lines (CAL27 and SCC15) were obtained from American Type Culture Collection (ATCC) (Manassas, VA, USA). All cancer cells were cultured in DMEM/F12 medium (a 1:1 mixture), supplemented with 10\% fetal bovine serum (FBS) and 1\% penicillin-streptomycin (P/S). Cancer cells were treated with different concentrations of drug for different time points in a humidified incubator with $5 \% \mathrm{CO}_{2}$ at $37^{\circ} \mathrm{C}$.

\section{MTT assay}

TBMS1-related tumor cell proliferation inhibition was detected by MTT assay. Cells were seeded in 96-well plates at 1,000 cells/well and treated with different concentrations of TBMS1 for different days. Then, each well was incubated at $37^{\circ} \mathrm{C}$ for $4 \mathrm{~h}$ with $20 \mu \mathrm{L}$ MTT in $200 \mu \mathrm{L}$ medium. Subsequently, the medium was removed and replaced by $150 \mu \mathrm{L}$ DMSO; 10 min later, the blue crystals dissolved. The OD values were detected at a wavelength of $560 \mathrm{~nm}$ by a microplate reader.

\section{BrdU staining assay}

Cells $\left(2 \times 10^{4}\right)$ were seeded in 24-well culture plates and treated with different concentrations of TBMS1 for 24 and $48 \mathrm{~h}$, respectively. Then, BrdU was added into the medium at a ratio of 1:100 (BrdU:medium) for $2 \mathrm{~h}$. Cells were then washed twice with PBS and fixed by $4 \%$ paraformaldehyde at room temperature for $15 \mathrm{~min}$. Subsequently, cells were treated with $1 \mathrm{~N} \mathrm{HCL}$ for $20 \mathrm{~min}$ at $37^{\circ} \mathrm{C}$, blocked with $10 \%$ goat serum at room temperature for $2 \mathrm{~h}$, incubated with a rat primary antibody for another $2 \mathrm{~h}$ and later incubated with an Alexa Fluor $^{\circledR} 488$ goat anti-rat IgG secondary antibody for $1 \mathrm{~h}$. Finally, the cells were stained by DAPI for $15 \mathrm{~min}$. A Nikon 80i fluorescence microscope was applied to collect fluorescent images. All the percentages of BrdU-positive cells were calculated according to 10 microscopic fields.

\section{Soft agar assay}

Briefly, the solidified base agar (0.6\% Noble agar in DMEM/ F12 medium) was placed at the bottom of the six-well plates. Then, the complete medium containing 0.3\% Noble agar, $10 \mu \mathrm{mol} / \mathrm{L}(\mu \mathrm{M})$ TBMS1 and 700 cells was placed on the top of the base agar. Subsequently the six-well plates were incubated with $5 \% \mathrm{CO}_{2}$ at $37^{\circ} \mathrm{C}$ for $14-21$ days. Ultimately, the colonies were photographed and recorded after being stained by MTT.

\section{Cell apoptosis analysis}

TBMS1-related apoptosis in OSCC cells was investigated by flow cytometry according to the manufacturer's protocol. Cells $\left(1 \times 10^{6}\right)$ were treated with TBMS1 for $24 \mathrm{~h}$, collected by centrifugation at $250 \times g$ for $90 \mathrm{~s}$ and washed with cold PBS three times. Then, cells were resuspended in the solution containing $100 \mu \mathrm{L}$ of binding buffer, $5 \mu \mathrm{L}$ of Annexin V-FITC and $10 \mu \mathrm{L}$ of PI and incubated at room temperature for $15 \mathrm{~min}$. After cells were double-stained with Annexin 
V-FITC/PI, cell apoptosis was measured by a flow cytometer with fluorescence activated cell sorting (FACS) system.

\section{Wound healing assay}

Cells in logarithmic phase were centrifuged and seeded in six-well plates $\left(1 \times 10^{6}\right)$. When cells had grown more than $90 \%$ confluence, scratches were made with a $300-400 \mu \mathrm{m}$ pipette tip, ensuring that all the wounds we made had the same width at the beginning. After being washed twice with PBS to remove all debris, cells were incubated in serumfree medium with varying concentrations of TBMS1. Cells migrating and covering the wounded area were observed during the experiment. Photographs were taken after cells were cultured with TBMS1 for different time points.

\section{Transwell migration assay}

Cell migration ability was investigated by using a transwell chamber with multi-porous polycarbonate membrane $(8 \mu \mathrm{m}$ pore size) which allowed cells to pass through. Cells $\left(1 \times 10^{5}\right)$, resuspended in medium containing 1\% FBS and TBMS1 $(10 \mu \mathrm{M})$, were added to the upper chamber, while $500 \mu \mathrm{L}$ complete medium containing 10\% FBS and TBMS1 $(10 \mu \mathrm{M})$ was added to the lower chamber. After being incubated for $30 \mathrm{~h}$, the transwell chambers were rinsed with PBS three times, fixed with $4 \%$ paraformaldehyde for $15 \mathrm{~min}$ and then stained by $0.5 \%$ crystal violet for $15 \mathrm{~min}$. Subsequently, cells that did not migrate through the membrane were wiped with cotton strips. Finally, 10 pictures of cells that migrated across the membrane were randomly taken by an inverted phase contrast microscope for each chamber.

\section{Western blot assay}

Cells $\left(2 \times 10^{5}\right)$ were collected by centrifugation at $100 \times g$ for $5 \mathrm{~min}$ after being treated with TBMS1 for 24 and $48 \mathrm{~h}$. Then cells were lysed in a RIPA lysis buffer with phosphatase inhibitor and proteinase inhibitor for $30 \mathrm{~min}$, centrifuged for $15 \mathrm{~min}$ and finally we obtained the total protein. $12 \%$ SDS-PAGE gel was applied to separate protein with $30 \mu \mathrm{g}$ of total protein being assigned to each lane. Protein was transferred to the PVDF membrane. After being blocked by $5 \%$ bovine serum albumin, the membrane was incubated with primary antibody overnight at $4{ }^{\circ} \mathrm{C}$ and then incubated with horseradish peroxidase-conjugated secondary antibody at room temperature for $2 \mathrm{~h}$. Ultimately, changes in protein expression were examined by enhanced chemiluminescence reagent and Western blotting detection instrument. The primary antibodies were those we mentioned earlier, and the secondary antibodies were HRP-labeled goat anti-mouse $\mathrm{IgG}$ $(\mathrm{H}+\mathrm{L})$ and goat anti-rabbit $\mathrm{IgG}(\mathrm{H}+\mathrm{L})$.

\section{Statistical analysis}

All experiments were repeated independently at least three times to confirm the experimental results. Quantitative data were expressed as mean \pm SD. Significant difference was calculated by Student's $t$-test. Difference was considered statistically significant when $P$-value $<0.05$.

\section{Results \\ TBMSI suppressed the proliferation and colony formation of human OSCC cells}

To detect the effect of TBMS1 on human oral cancer cells, in the study, we treated OSCC cells with TBMS1. After cancer cells were treated with it $(0,2.5,5,10,15$ and $20 \mu \mathrm{M})$ for $0,1,3,5$ and 7 days, growth curves were drawn. The proliferation of TBMS1-treated cells was inhibited significantly compared with the control group (without TBMS1). Especially when exposed to high concentrations of TBMS1 (15 and $20 \mu \mathrm{M}$ ), cancer cell numbers decreased sharply (Figure 1B). By studying concentration-response curves, we calculated the $\mathrm{IC}_{50}$ of each cell line at different time points, for instance $\mathrm{IC}_{50}$ for $\mathrm{SCC} 15$ at $24 \mathrm{~h}$ was $11.6 \mu \mathrm{M}$ and $\mathrm{IC}_{50}$ for CAL27 at $24 \mathrm{~h}$ was $14.6 \mu \mathrm{M}$. Therefore, we determined the concentrations of TBMS1 $(0,5,10$ and $15 \mu \mathrm{M})$ for the subsequent experiments by the MTT experiment. Cell morphology was observed, and cell numbers were counted through a microscope. Figure $1 \mathrm{C}$ and $\mathrm{D}$ indicates that cell morphology changed conspicuously and cell numbers declined dramatically in a dose- and time-dependent manner. Additionally, BrdU staining assay was conducted to investigate cell growth and proliferation as well. Percentages of BrdU-positive cells treated with TBMS1 (2.5, 5 and $10 \mu \mathrm{M})$ decreased significantly when compared with the control group, except for the CAL27 cells which reduced slightly after being treated with $2.5 \mu \mathrm{M}$ TBMS1 for $24 \mathrm{~h}$ (Figure 1E-G). In this study, the colony formation ability of cells in vitro was assessed by soft agar assay. Compared with the control group, the TBMS1-treated group $(10 \mu \mathrm{M})$ formed less and smaller spherical colonies in soft agar (Figure 2A-B), and the difference was statistically significant (Figure 2C).

\section{TBMSI inhibited the migration of human OSCC cells}

A wound healing assay and transwell migration assay were carried out to explore the migration ability of oral cancer cells. Figure 3A shows that as time went by, the wound area of all groups got smaller. However, the wound area of groups treated with TBMS1 $(5$ and $10 \mu \mathrm{M})$ distinctly surpassed that 
A
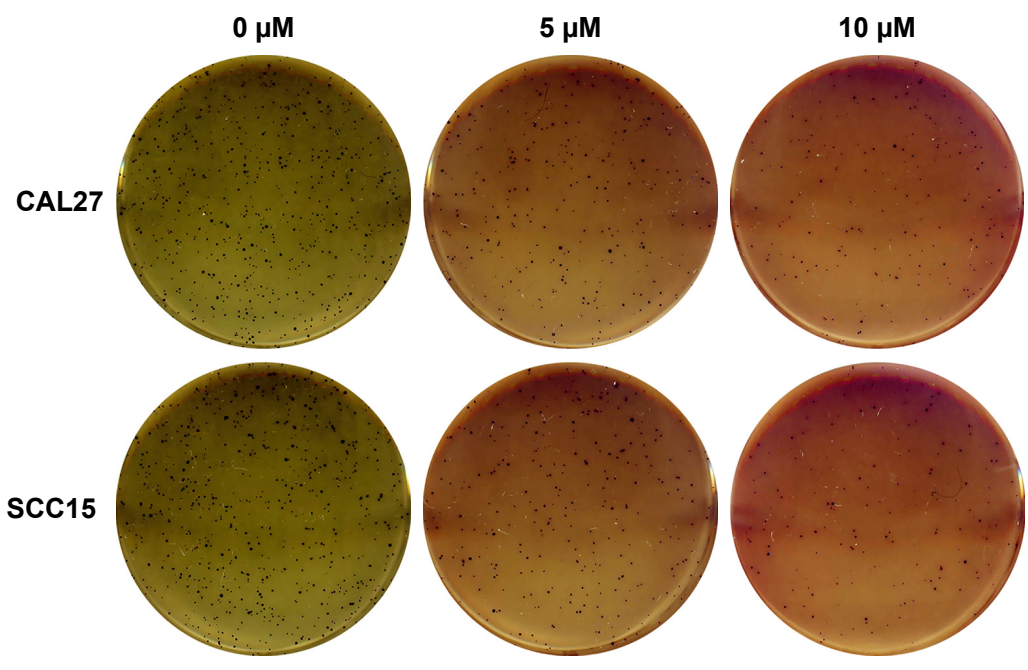

B
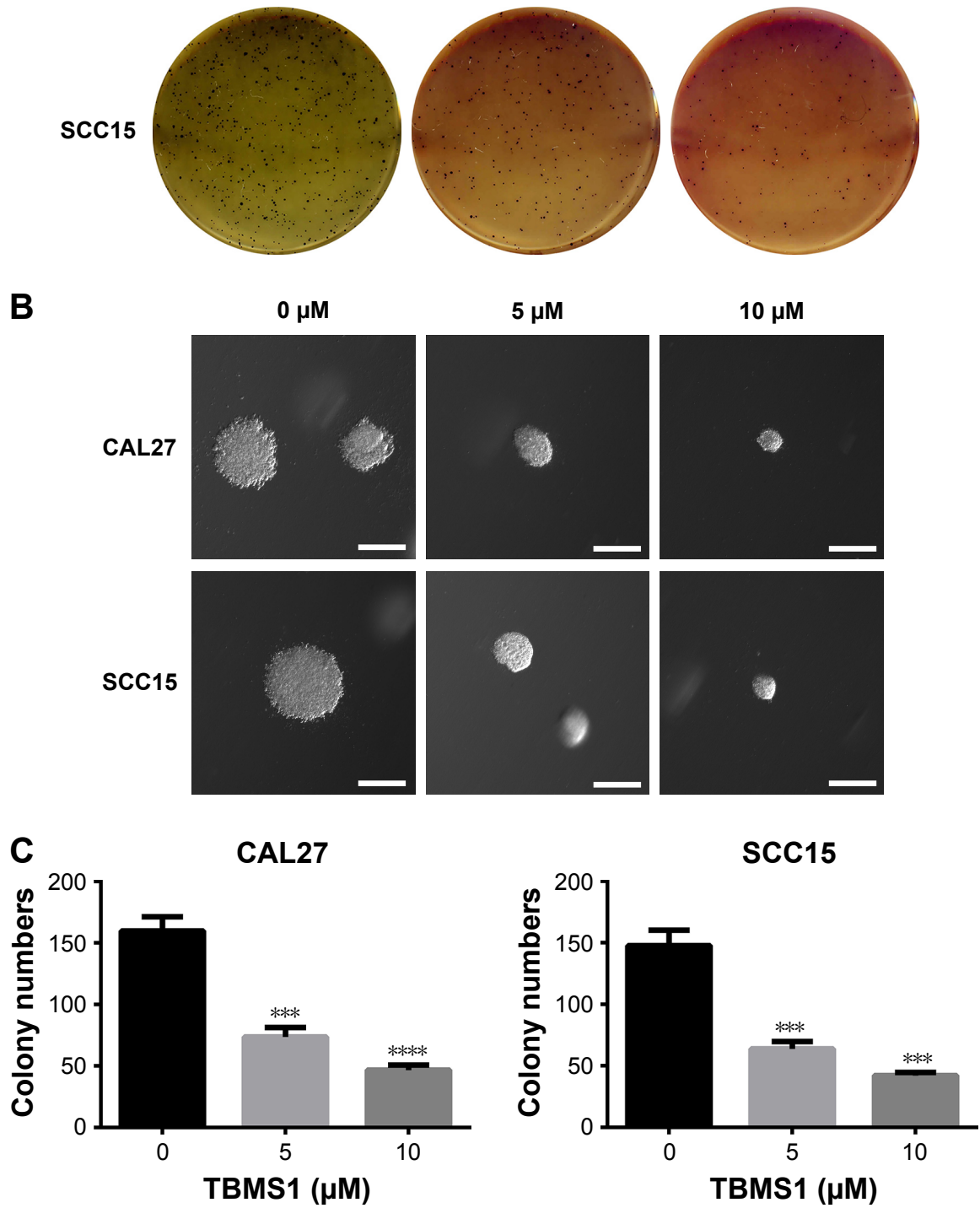

Figure 2 TBMSI inhibited colony formation ability of OSCC cells in vitro.

Notes: (A) Colonies of CAL27 and SCCI5 cells are shown by pictures taken by a scanner after cells being treated with $10 \mu \mathrm{M}$ TBMSI. (B) Micromorphology of colonies in soft agar was exhibited by photographs through an inverted microscope after cells were treated under the same conditions. Scale bar I00 $\mu \mathrm{m}$. (C) Colony numbers of cells treated with 0 and $10 \mu \mathrm{M}$ of TBMSI were computed. All data were presented as mean \pm SD. $* * * P<0.00$ I, $* * * * P<0.000$ I compared with the control group $(0 \mu \mathrm{M})$. Abbreviations: $\mu \mathrm{M}, \mu \mathrm{mol} / \mathrm{L}$; TBMSI, tubeimoside-I; OSCC, oral squamous cell carcinoma.

of the control group at 12, 24, 36 and $48 \mathrm{~h}$. Likewise, in the transwell assay (Figure 3B) the number of cells that migrated through the multiporous polycarbonate membrane in groups treated with TBMS1 decreased strikingly when compared with the control group and the quantitative analysis further showed that the difference was statistically significant
(Figure 3C). Subsequently, Western blot assay was applied to further detect c-Myc and MMP-7 expression. c-Myc, a key member of the myc gene family, is highly expressed in $>30 \%$ of human cancers and regulates different physiological processes $^{7}$ such as metastasis in bladder cancer cells. ${ }^{8}$ Matrix metalloproteinases (MMPs) are zinc-dependent proteolytic 
A
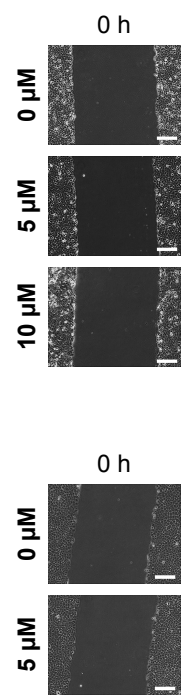

$\sum_{\substack{2\\}}$
CAL27
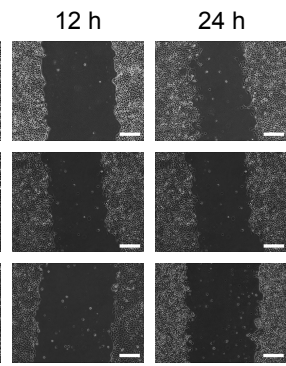
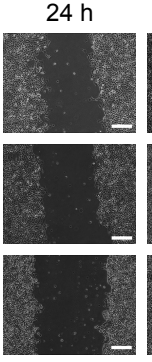

SCC15

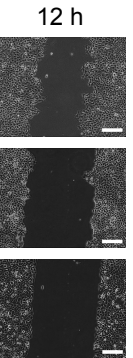

D

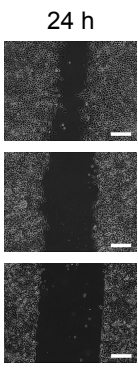

CAL27
B

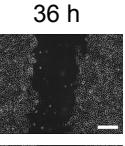

$48 \mathrm{~h}$
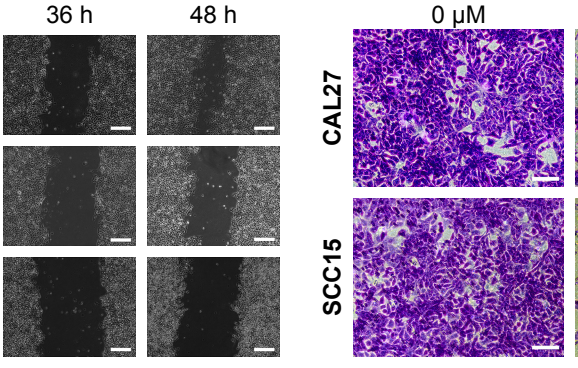

$10 \mu \mathrm{M}$

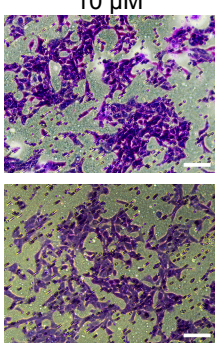

C

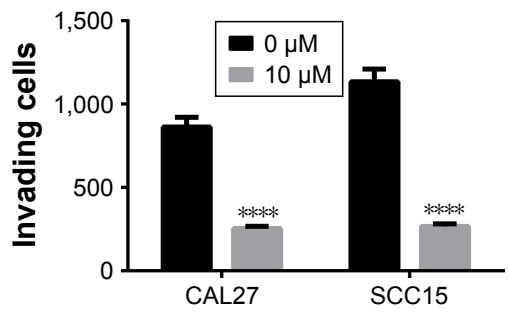

SCC15

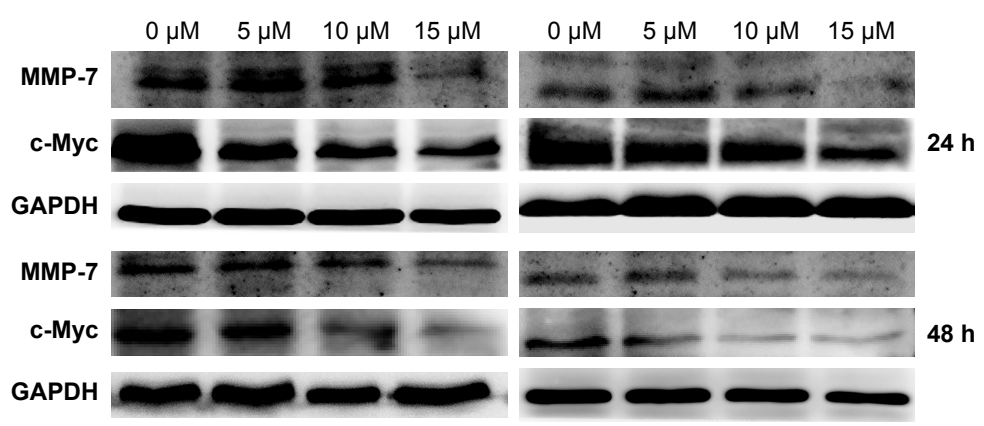

CAL27

SCC15
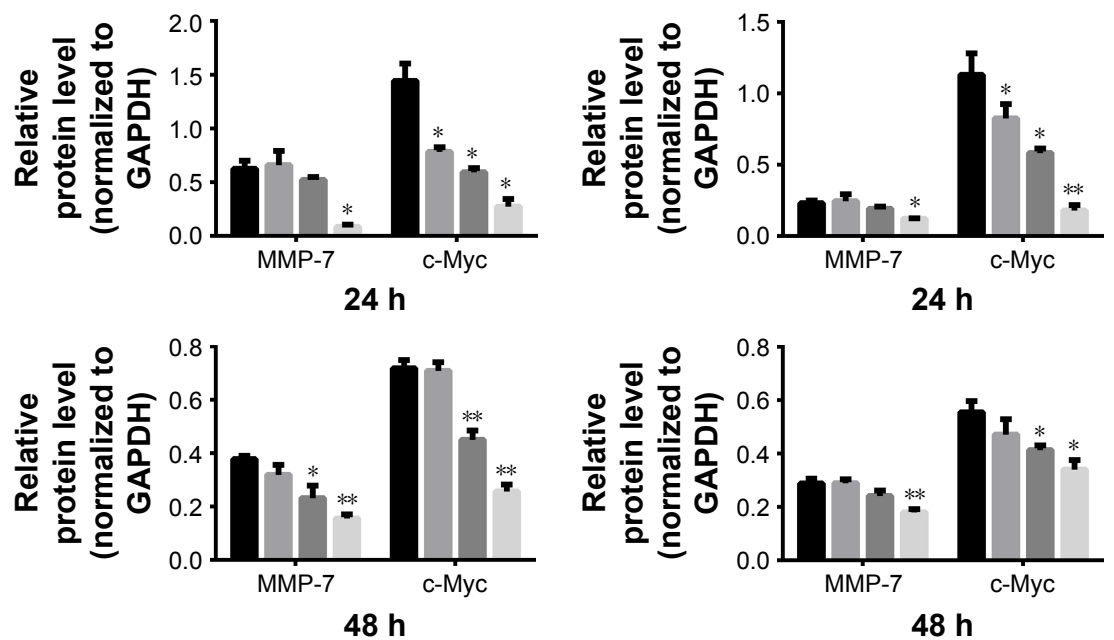

$48 \mathrm{~h}$

$48 \mathrm{~h}$

$0 \mu \mathrm{M}-5 \mu \mathrm{M} \quad 10 \mu \mathrm{M} \square 15 \mu \mathrm{M}$

Figure 3 TBMSI suppressed migration of OSCC cells in vitro.

Notes: (A) Wound healing assay was carried out to detect the effect of TBMSI on the migration of CAL27 and SCCI5 cells. Scale bar I00 $\mu$ m. (B and C) Transwell assay was also performed after OSCC cells were treated with TBMSI and the cells that migrated across the membrane were photographed and counted through repeated tests. Scale bar $50 \mu \mathrm{m}$. (D) c-Myc and MMP-7 expression was reduced by TBMSI in OSCC cells at 24 and $48 \mathrm{~h}$, respectively. All data were presented as the mean \pm SD. $* P<0.05$, $* * P<0.01$, $* * * * P<0.0001$ compared with the control group $(0 \mu \mathrm{M})$.

Abbreviations: $\mu \mathrm{M}, \mu \mathrm{mol} / \mathrm{L}$; h, hours; TBMSI, tubeimoside-I; OSCC, oral squamous cell carcinoma. 
enzymes, which have many physiological functions, for instance, degradation of protein components in extracellular matrix. Previous studies suggest that MMP-7 is closely related to cancer progression and metastasis. It could enhance the metastatic potential of colon cancer cells. ${ }^{9-11}$ Our data demonstrated that TBMS1 significantly inhibited intracellular expression of MMP-7 after cancer cells being treated with 10 and $15 \mu \mathrm{M}$ TBMS1. TBMS1 also decreased c-Myc expression obviously (Figure 3D).

\section{TBMSI induced apoptosis in human OSCC cells}

OSCC cells, treated with TBMS1 ( 0 and $10 \mu \mathrm{M})$ for $24 \mathrm{~h}$, were collected and examined via flow cytometry using Annexin V-FITC/PI double-staining. The results showed that TBMS1 increased the percentages of apoptosis cells from $4.38 \%$ to $12.99 \%$ in CAL27 cells and from $5.05 \%$ to $13.99 \%$ in SCC 15 cells (Figure 4A), and the difference was statistically significant (Figure 4B). The result by flow cytometry suggested that
A

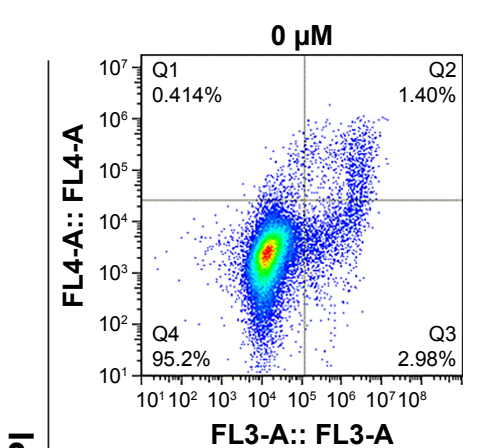

$\bar{\alpha}$

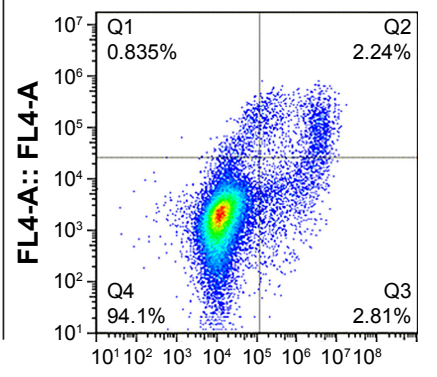

FL3-A:: FL3-A

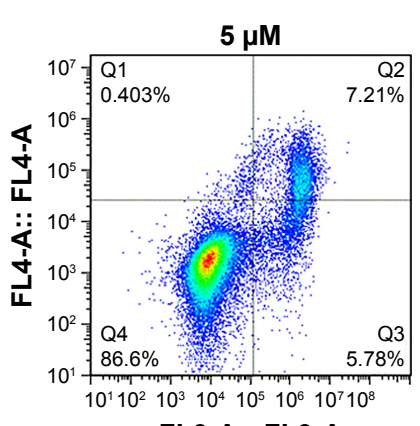

FL3-A:: FL3-A

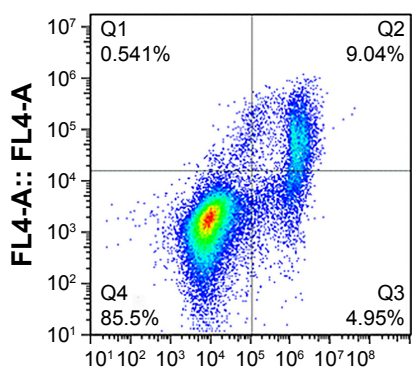

FL3-A:: FL3-A
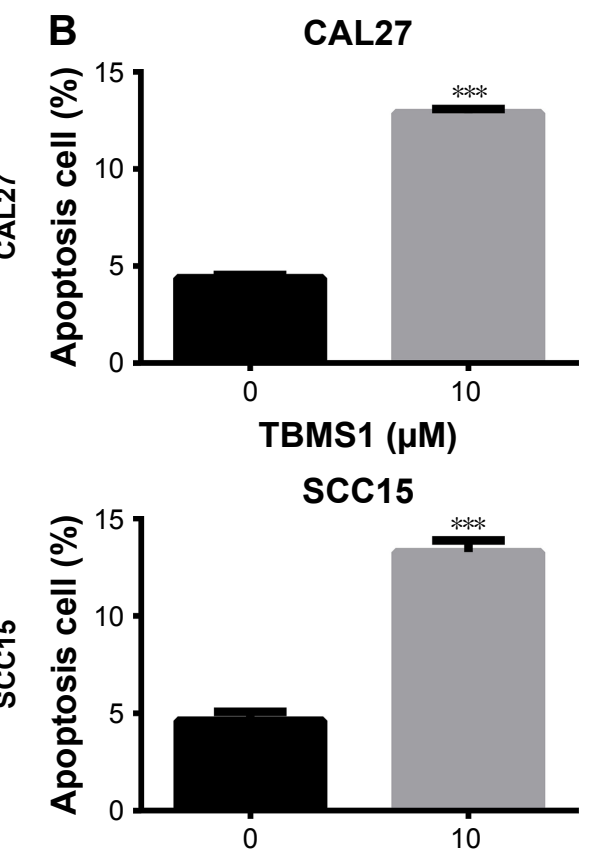

TBMS1 ( $\mu \mathrm{M})$

FITC Annexin-V

C

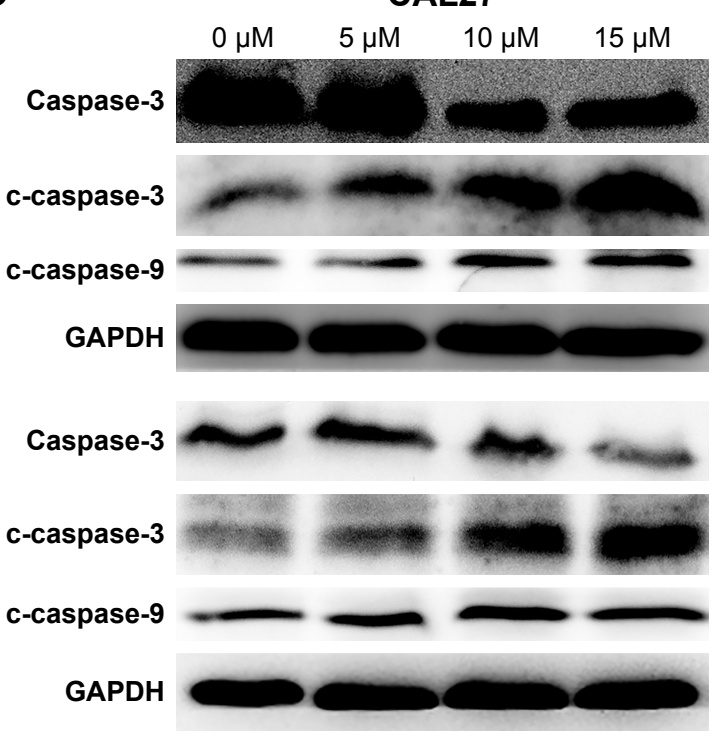

CAL27

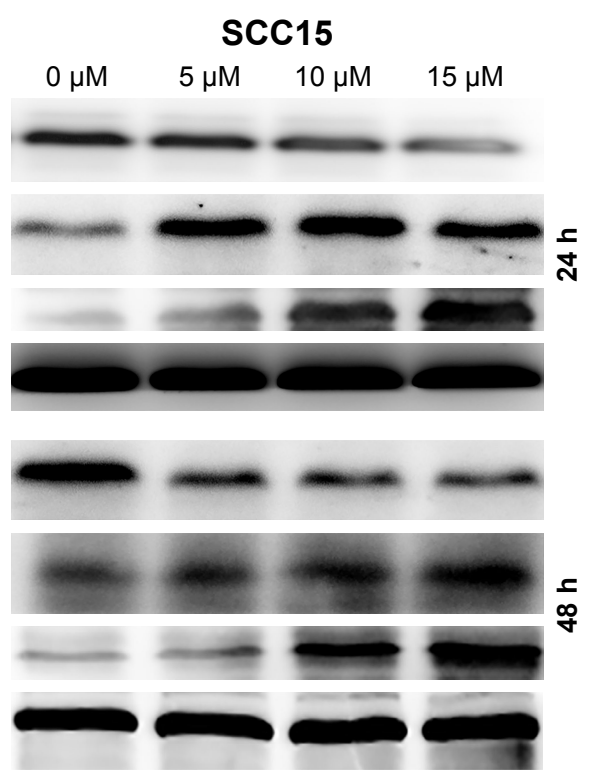

Figure 4 (Continued) 

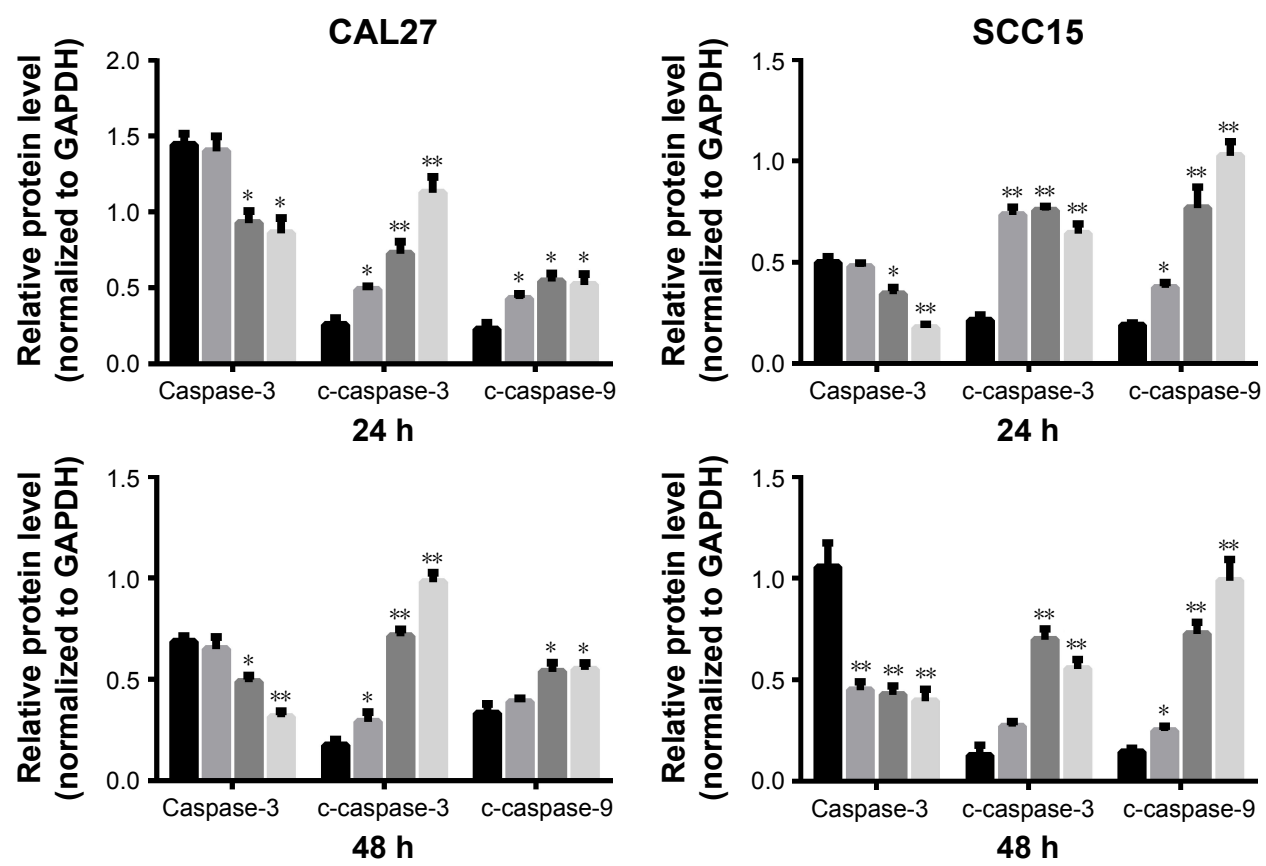

$0 \mu \mathrm{M} \quad 5 \mu \mathrm{M} \quad 10 \mu \mathrm{M} \quad 15 \mu \mathrm{M}$

D

CAL27

$\operatorname{SCC} 15$

$0 \mu \mathrm{M} \quad 5 \mu \mathrm{M} \quad 10 \mu \mathrm{M} \quad 15 \mu \mathrm{M} \quad 0 \mu \mathrm{M} \quad 5 \mu \mathrm{M} \quad 10 \mu \mathrm{M} \quad 15 \mu \mathrm{M}$

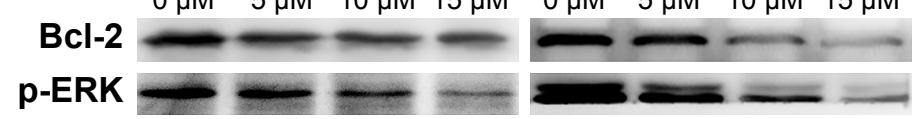

PARP $\longrightarrow-\cdots-\cdots$

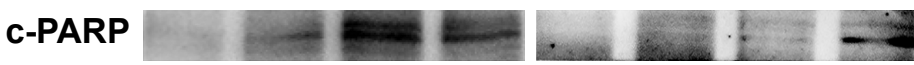

GAPDH
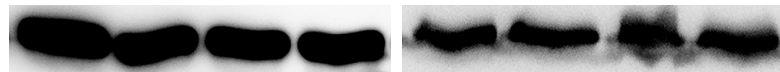

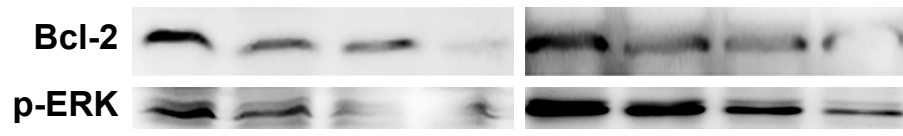

ERK

PARP $-\longrightarrow-1-\square$

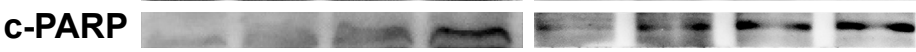

GAPDH
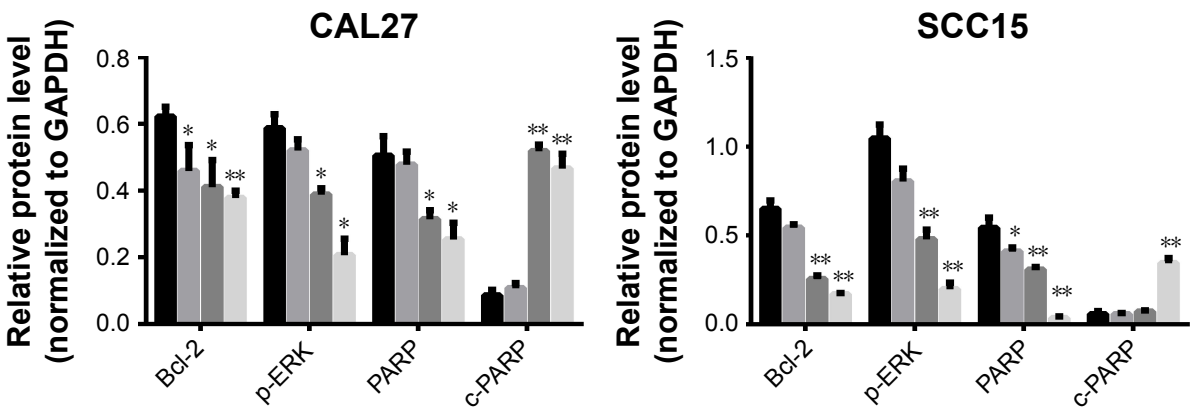

$24 \mathrm{~h}$

$24 \mathrm{~h}$

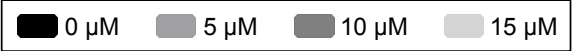

Figure 4 (Continued) 


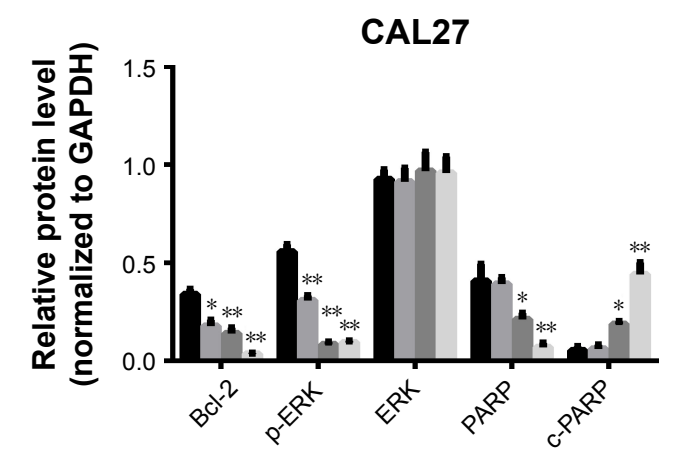

$48 \mathrm{~h}$

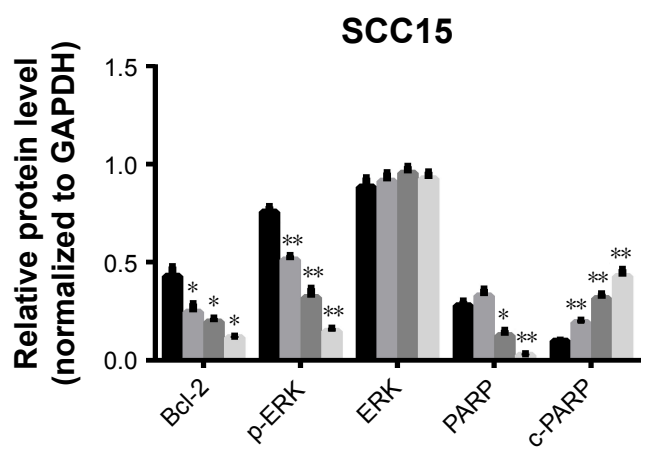

$48 \mathrm{~h}$

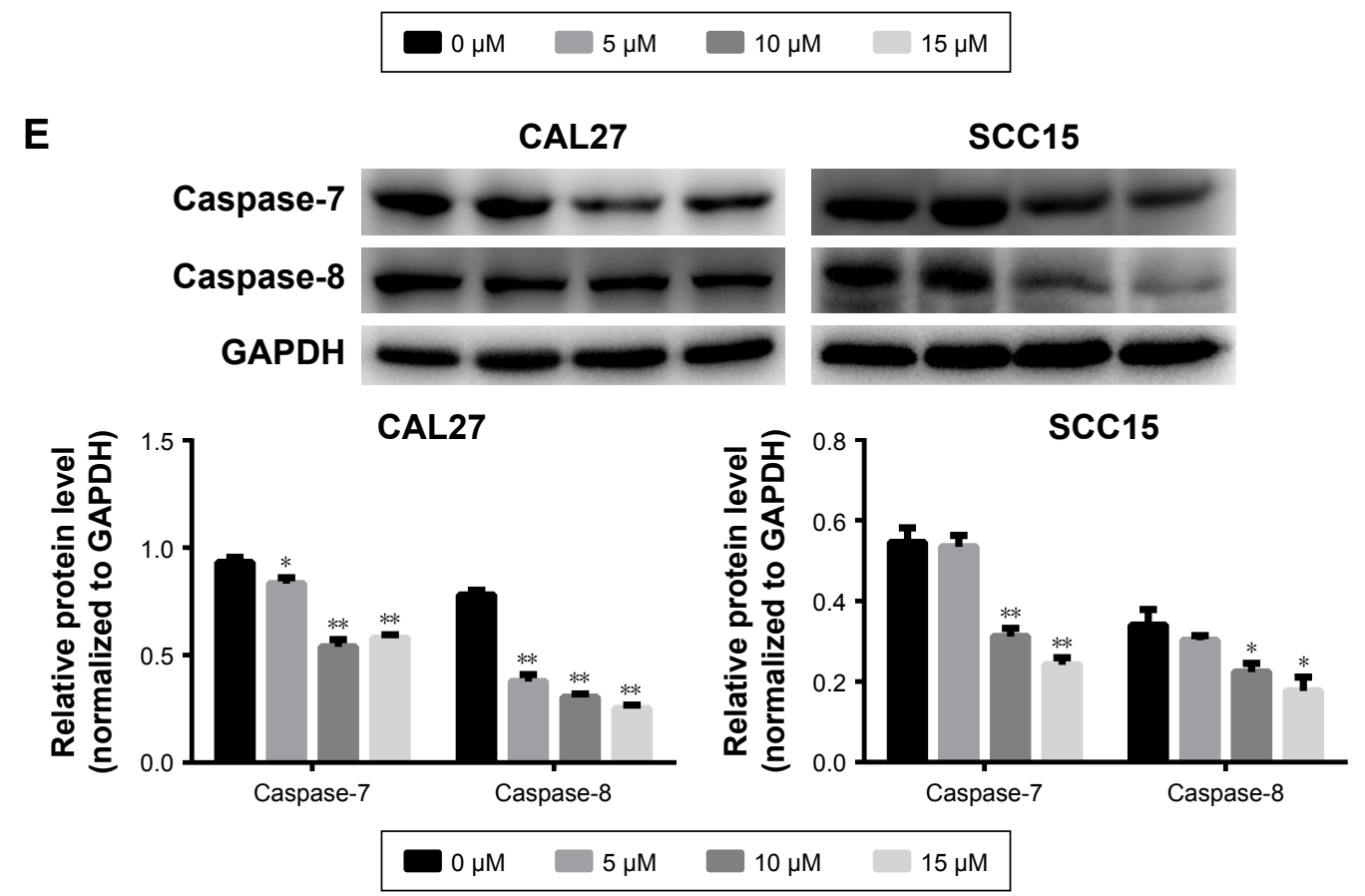

Figure 4 TBMSI induced apoptosis in OSCC cells.

Notes: (A and B) Flow cytometry was utilized to explore the apoptosis after cells were stained by Annexin V and PI. (C and D) Effect of TBMSI on the expression of caspase-3, caspase- 9 and other intrinsic pathway-related proteins in CAL27 and SCCI 5 cells was investigated by Western blot assay after cells being treated with TBMSI for 24 and 48 h. (E) The expression of extrinsic pathway-related proteins caspase-7 and caspase-8 was explored after OSCC cells were treated with TBMSI for 48 h. All data were presented as mean $\pm S D$. $* P<0.05$, $* * P<0.01$, and $* * * P<0.001$ compared with the control group $(0 \mu \mathrm{M})$.

Abbreviations: $\mu \mathrm{M}, \mu \mathrm{mol} / \mathrm{L}$; TBMSI, tubeimoside-I; h, hours; FITC, fluorescein isothiocyanate; PI, propidium iodide; OSCC, oral squamous cell carcinoma.

TBMS1 absolutely induced apoptosis in SCC15 and CAL27 cells, but we did not know the underlying mechanisms. Therefore, cells exposed to increasing concentrations of TBMS $1(0,5,10$ and $15 \mu \mathrm{M})$ for 24 and $48 \mathrm{~h}$ were collected and used for Western blot assay to detect the apoptosisrelated proteins. Caspases are executioners of apoptosis which play a pivotal role in apoptosis-related death. ${ }^{12}$ In this study, we mainly explored the effect of TBMS1 on caspase-3, caspase-7, caspase- 8 and caspase-9. Figure $4 \mathrm{C}$ illustrates that the expression level of caspase- 3 decreased when compared with the control group at 24 and $48 \mathrm{~h}$. In contrast, TBMS1 upregulated the expression of c-caspase- 3 and c-caspase- 9 in a concentration-dependent manner. Additionally, Figure 4E shows that TBMS1 could obviously downregulate caspase-7 and caspase- 8 expression.

\section{TBMSI induced intrinsic cellular apoptosis via ERKI/2/Bcl-2 pathway}

In order to further study the mechanism of TBMS1, cells treated under the same conditions were harvested to evaluate the expression of ERK1/2, Bcl-2, p-ERK1/2, PARP and c-PARP. Bcl-2 family proteins are crucial in deciding the apoptotic procedure in vivo. They can be divided into antiapoptotic and pro-apoptotic proteins, and the Bcl-2 we 
detected is one of the anti-apoptotic members. ${ }^{12}$ Figure 4D shows that the product level of Bcl-2 in cells treated with TBMS1 declined when compared with the control group and TBMS1 also downregulated p-ERK1/2 expression with increasing drug concentrations, while the total ERK1/2 expression remained unchanged. After exposure to TBMS1, product level of c-PARP increased in a dose-dependent manner, however, PARP expression decreased at high dose of TBMS1 (10 and $15 \mu \mathrm{M})$.

\section{Discussion}

In this study, our data showed that TBMS1 suppressed the growth of CAL27 and SCC15 cells in a time- and dosedependent manner and it weakened the colony formation ability of cells in vitro. TBMS1 was studied to modulate the colorectal cancer cell invasion and repress breast cancer cell metastasis in vitro. ${ }^{13,14}$ Downexpression of MMP-7 was involved in restraining gastric cancer cell migration. ${ }^{15} \mathrm{~A}$ previous study uncovered that histone methyltransferase SET 8 knockdown inhibited invasion by mediating the expression of the Wnt/B-catenin target genes c-Myc and MMP-7 in renal carcinoma cells. ${ }^{16}$ In this study, migration inhibition was detected by wound healing and transwell migration assays. However, the molecular mechanism was unclear. So oncoproteins c-Myc and MMP-7 were investigated, and their expression was reduced by TBMS1. Therefore, TBMS1 might induce metastasis inhibition in OSCC cells through decreasing c-Myc and MMP-7 protein expression.

We observed TBMS1-induced apoptosis through the flow cytometry assay as well. Currently, there are mainly two apoptotic signaling pathways, ${ }^{17}$ and the intrinsic apoptosis pathway is described briefly as follows: various apoptotic signals change mitochondrial membrane permeability to release corresponding pro-apoptotic factors into the cytoplasm, which subsequently promotes the formation of apoptosome. Then, the apoptosome recruits and activates pro-caspase-9. Mature caspase-9 further activates other proteins such as caspase-3. Finally, activated caspase- 3 cleaves PARP and induces cell apoptosis. ${ }^{18-20}$ However, the above mentioned protein cascade reactions are regulated by the Bcl-2 family. ${ }^{19}$ Therefore, apoptosis is an extremely complicated reaction process. Recently, the cell apoptosis effect caused by a host of chemotherapeutic drugs including TBMS1 has been explored. TBSM1 could induce proliferation inhibition and advance apoptosis in HepG2 cells. ${ }^{12,21}$ Caspases and the Bcl-2 protein family played a crucial role in TBMS1-induced apoptosis in human choriocarcinoma cells, glioma cells and prostate carcinoma cells. ${ }^{22-24}$ Consequently, we investigated caspase-3, c-caspase-3, -9 and
Bcl-2 expression in TBMS1-treated cells, which were well documented as the key proteins in intrinsic apoptosis pathway. We also detected caspase-8, the critical initiator of the extrinsic signaling pathway, and its downstream effector caspase-7. Our results showed that TBMS1 increased the c-caspase- 3 and -9 expression and decreased the expression of caspase-3, Bcl-2, caspase- 7 and caspase- 8 , which validated the conjecture about the intrinsic and extrinsic apoptosis pathways.

We also investigated PARP and ERK1/2 expression changes, which played crucial roles in TBMS1-induced apoptosis. ${ }^{22,25-27}$ ERK1/2, belonging to the MARP family, is indispensable in determining cell survival and convincing evidence indicates that MARP pathways are involved in chemotherapy-induced apoptosis. ${ }^{28}$ TBMS1 altered the phosphorylation of ERK1/2. ${ }^{22,25}$ It has been reported that ERK1/2 regulates the expression of $\mathrm{Bcl}-2$, which partly contributes to the presumption that ERK $1 / 2$ is the upstream effector of Bcl-2. ${ }^{29}$ Consistent with the available studies, our data pointed out that various concentrations of TBMS1 increased c-PARP expression, accompanied by the decrease in total PARP expression after cells were treated with high doses of TBMS1, and TBMS1 markedly inhibited p-ERK1/2 expression, which leads to the Bcl-2 product decline in this study. Therefore, our results revealed that TBMS1 might induce intrinsic apoptosis through the ERK1/2/Bcl-2/caspase-9/caspase-3/PARP pathway, and the extrinsic apoptotic pathway was also involved in cellular apoptosis. Apart from the effects we described earlier, TBMS1 was reported to possess anti-microtubule activity in $\mathrm{CNE}-2 \mathrm{Z}$ cell $^{30}$ and as well as inhibited angiogenesis of lung cancer through VEGFR and Tie2 signalings. ${ }^{31}$ Consequently, it is important to do more research to ascertain the complicated mechanism of TBMS1 in OSCC cells.

Taken together, the study results illuminated that TBMS1 indeed inhibited cell proliferation and migration ability visibly. It also induced apoptosis in OSCC cells. Hence, our data may provide a powerful clue for TBMS1 to be a potential chemotherapeutic drug for OSCC.

\section{Acknowledgments}

This study was supported by China Postdoctoral Science Foundation (2013M542248), Open Project of State Key Laboratory of Silkworm Genome Biology (20120015), the National Natural Science Foundation of China (81672502), Nature Science Foundation of Yuzhong District of Chongqing (20140128), program for innovation team building at institutions of higher education in Chongqing in 2016 (CXTDG201602006) and Chongqing municipal key laboratory of oral biomedical engineering of higher education. 


\section{Disclosure}

The authors report no conflicts of interest in this work.

\section{References}

1. Radhika T, Jeddy N, Nithya S, Muthumeenakshi RM. Salivary biomarkers in oral squamous cell carcinoma - an insight. J Oral Biol Craniofac Res. 2016;6:S51-S54.

2. Wang F, Ma R, Yu L. Role of mitochondria and mitochondrial cytochrome $\mathrm{c}$ in tubeimoside I-mediated apoptosis of human cervical carcinoma HeLa cell line. Cancer Chemother Pharmacol. 2006;57(3): 389-399.

3. Ma RD, Yu LJ, Su WM, et al. Induction of cell cycle arrest and apoptosis by Tubeimoside-1 isolated from Bolbostemma paniculatum in HeLa cells. Chin J Clin Pharmacol Ther. 2004;9(3):261-269. Available from: http://kreader.cnki.net/Kreader/CatalogViewPage.aspx?dbCode=CJFQ \&filename $=$ YLZL200403006\& tablename $=$ CJFD2004\&compose $=\&$ fi rst $=1 \&$ uid $=$. Accessed June 20, 2018.

4. Xu Y, Ching YP, Zhou Y, Chiu JF, Chen F, He QY. Multiple pathways were involved in tubeimoside-1-induced cytotoxicity of HeLa cells. J Proteomics. 2011;75(2):491-501.

5. Hao W, Wang S, Zhou Z. Tubeimoside-1 (TBMS1) inhibits lung cancer cell growth and induces cells apoptosis through activation of MAPKJNK pathway. Int J Clin Exp Pathol. 2015;8(10):12075-12083.

6. Zhang Y, Xu X, He P. Tubeimoside-1 inhibits proliferation and induces apoptosis by increasing the Bax to Bcl-2 ratio and decreasing COX-2 expression in lung cancer A549 cells. Mol Med Rep. 2011; $4(1): 25-29$.

7. You Z, Madrid LV, Saims D, Sedivy J, Wang C-Y. c-Myc sensitizes cells to tumor necrosis factor-mediated apoptosis by inhibiting nuclear factor kappa B transactivation. J Biol Chem. 2002;277(39):36671-36677.

8. Mao XW, Xiao JQ, Xu G, et al. CUL4B promotes bladder cancer metastasis and induces epithelial-to-mesenchymal transition by activating the Wnt/ $\beta$-catenin signaling pathway. Oncotarget. 2017;8(44): $77241-77253$.

9. Ishikawa T, Kimura Y, Hirano H, Higashi S. Matrix metalloproteinase-7 induces homotypic tumor cell aggregation via proteolytic cleavage of the membrane-bound Kunitz-type inhibitor HAI-1. J Biol Chem. 2017;292(50):20769-20784.

10. Nagase H, Visse R, Murphy G. Structure and function of matrix metalloproteinases and TIMPs. Cardiovasc Res. 2006;69:562-573.

11. Egeblad M, Werb Z. New functions for the matrix metalloproteinases in cancer progression. Nat Rev Cancer. 2001;2(3):161-174.

12. Yin $\mathrm{Y}$, Chen $\mathrm{W}$, Tang $\mathrm{C}$, et al. NF- $\mathrm{KB}$, JNK and $\mathrm{p} 53$ pathways are involved in tubeimoside-1-induced apoptosis in HepG2 cells with oxidative stress and G2/M cell cycle arrest. Food Chem Toxicol. 2011;49: 3046-3054.

13. Bian Q, Liu P, Gu J, Song B. Tubeimoside-1 inhibits the growth and invasion of colorectal cancer cells through the Wnt/ $\beta$-catenin signaling pathway. Int J Clin Exp Pathol. 2015;8(10):12517-12524.

14. Peng Y, Zhong Y, Li G. Tubeimoside-1 suppresses breast cancer metastasis through downregulation of CXCR4 chemokine receptor expression. BMB Rep. 2016;49(9):502-507.
15. Xiang J, Fu X, Ran W, Wang Z. Grhl2 reduces invasion and migration through inhibition of TGF $\beta$-induced EMT in gastric cancer. Oncogenesis. 2017;6(1):e284

16. Zhang S, Guo Z, Xu J, et al. miR-502-mediated histone methyltransferase SET8 expression is associated with clear cell renal cell carcinoma risk. Oncol Lett. 2017;14(6):7131-7138.

17. Kroemer G, Reed JC. Mitochondrial control of cell death. Nat Med. 2000;6(5):513-519.

18. Waxman DJ, Schwartz PS. Harnessing apoptosis for improved anticancer gene therapy. Cancer Res. 2003;63(24):8563-8572.

19. Chinnaiyan AM. The apoptosome: heart and soul of the cell death machine. Neoplasia. 1999;1(1):5-15.

20. Cain K, Bratton SB, Cohen GM. The Apaf-1 apoptosome: a large caspase-activating complex. Biochimie. 2002;84(2-3):203-214.

21. Wang Y, Deng L, Zhong H, Wang Y, Jiang X, Chen J. Natural plant extract tubeimoside I promotes apoptosis-mediated cell death in cultured human hepatoma (HepG2) cells. Biol Pharm Bull. 2011;34(6): 831-838.

22. Huang P, Yu C, Liu XQ, Ding YB, Wang YX, He JL. Cytotoxicity of tubeimoside I in human choriocarcinoma JEG-3 cells by induction of cytochrome c release and apoptosis via the mitochondrial-related signaling pathway. Int J Mol Med. 2011;28(4):579-587.

23. Yang JB, Khan M, He YY, et al. Tubeimoside-1 induces oxidative stressmediated apoptosis and $\mathrm{G}_{0} / \mathrm{G}_{1}$ phase arrest in human prostate carcinoma cells in vitro. Acta Pharmacologica Sinica. 2016;37:950-962.

24. Jia G, Wang Q, Wang R, et al. Tubeimoside-1 induces glioma apoptosis through regulation of BAX/BCL-2 and the ROS/Cytochrome C/ Caspase-3 pathway. Onco Targets Ther. 2015;8:303-311.

25. Liu HZ, Yu C, Yang Z, et al. Tubeimoside I sensitizes cisplatin in cisplatin-resistant human ovarian cancer cells (A2780/DDP) through down-regulation of ERK and up-regulation of $\mathrm{p} 38$ signaling pathways. Mol Med Rep. 2011;4(5):985-992.

26. Lin Y, Xie G, Xia J, et al. TBMS1 exerts its cytotoxicity in NCI-H460 lung cancer cells through nucleolar stress-induced p53/MDM2dependent mechanism, a quantitative proteomics study. Biochim Biophys Acta. 2016;1864(2):204-210.

27. Xu Y, Wang G, Chen Q, et al. Intrinsic apoptotic pathway and G2/M cell cycle arrest involved in tubeimoside I-induced EC109 cell death. Chin J Cancer Res. 2013;25(3):312-321.

28. Makin G, Dive C. Modulating sensitivity to drug-induced apoptosis: the future for chemotherapy? Breast Cancer Res. 2001;3(3):150-153.

29. Chen WJ, Yu C, Yang Z, et al. Tubeimoside-1 induces G2/M phase arrest and apoptosis in SKOV-3 cells through increase of intracellular $\mathrm{Ca} 2+$ and caspase-dependent signaling pathways. Int J Oncol. 2012; 40(2):535-543.

30. Ma R, Song G, You W, et al. Anti-microtubule activity of tubeimoside-1 and its colchicine binding site of tubulin. Cancer Chemother Pharmacol. 2008;62(4):559-568.

31. Gu Y, Körbel C, Scheuer C, et al. Tubeimoside-1 suppresses tumor angiogenesis by stimulation of proteasomal VEGFR2 and Tie2 degradation in a non-small cell lung cancer xenograft model. Oncotarget. 2016;7(5):5258-5272.
OncoTargets and Therapy

\section{Publish your work in this journal}

OncoTargets and Therapy is an international, peer-reviewed, open access journal focusing on the pathological basis of all cancers, potential targets for therapy and treatment protocols employed to improve the management of cancer patients. The journal also focuses on the impact of management programs and new therapeutic agents and protocols on

Submit your manuscript here: http://www.dovepress.com/oncotargets-and-therapy-journal
Dovepress

patient perspectives such as quality of life, adherence and satisfaction. The manuscript management system is completely online and includes a very quick and fair peer-review system, which is all easy to use. Visit http://www.dovepress.com/testimonials.php to read real quotes from published authors. 